\title{
PENGARUH MANFAAT, KEPERCAYAAN DAN KEMUDAHAN PENGGUNAAN TERHADAP MINAT NASABAH MENGGUNAKAN MOBILE BANKING DI BANK MEGA SYARIAH CABANG PALU
}

\author{
Nurdin Nurdin'1, Rukma Ningrum², Sofyan Bachmid³, Abdul Jalil ${ }^{4}$ \\ ${ }^{1}$ Jurusan Perbankan, Fakultas Ekonomi dan Bisnis Islam, IAIN Palu, \\ 2 Jurusan Perbankan, Fakultas Ekonomi dan Bisnis Islam, IAIN Palu, Rukmaningrum19@gmail.com \\ ${ }^{3}$ Jurusan Perbankan, Fakultas Ekonomi dan Bisnis Islam, IAIN Palu, \\ ${ }^{4}$ Jurusan Perbankan, Fakultas Ekonomi dan Bisnis Islam, IAIN Palu, abdul_jaliil@iainpalu.ac.id
}

ABSTRAK

Pada era teknologi informasi sekarang ini perilaku nasabah atau konsumen banyak berubah dalam melakukan transaksi perbankan, dimana nasabah sangat mengedepankan aspek kemudahan, fleksibilitas, efisiensi, dan kesederhanaan. Teknologi mobile banking merupakan salah satu jenis pelayanan yang diberikan Bank MEGA Syariah kepada nasabahnya agar nasabah dapat melakukan transaksi perbankan kapan saja dan dimana saja setiap saat tanpa harus dating ke bank yang bersangkutan. Jenis penelitian ini adalah penelitian kuantitatif dengan sifat asosiatif. Sumber data dalam penelitian ini adalah data primer dan data sekunder. Sampel penelitian ini sebanyak 62 responden yang diambil dengan teknik incidental sampling. Teknik pengumpulan data menggunakan kuesioner dan wawancara. Metode analisis data menggunakan uji regresi linier berganda. Dari hasil uji t menunjukkan bahwa variabel manfaat memiliki nilai $\mathrm{T}_{\text {hitung }}$ sebesar $1.378<1.988$, maka $\mathrm{H}_{1}$ ditolak, variabel kepercayaan memiliki nilai $\mathrm{T}_{\text {hitung }}$ sebesar $2.208>1.988$, maka $\mathrm{H}_{2}$ diterima, variabel kemudahan penggunaan memiliki nilai $\mathrm{T}_{\text {hitung }}$ sebesar $1.785<1.988$, maka $\mathrm{H}_{3}$ ditolak. Dan hasil uji $\mathrm{R}^{2}$ sebesar 0.301, hal tersebut berarti variabel minat nasabah dapat dijelaskan oleh variabel manfaat, kepercayaan, dan kemudahan penggunaan. Secara parsial dari tiga variable yang diuji tidak satupun mempengaruhi minat nasabah menggunakan mobile banking.
INFORMASI

ARTIKEL

Katakunci:

Manfaat,

Kepercayaan, Kemudahan, Minat

Nasabah 


\section{PENDAHULUAN}

Strategi

pengembangan perbankan syariah diarahkan untuk meningkatkan kompetisi usaha yang sejajar dengan sistem perbankan konvensional yang dilakukan secara komprehensip dengan mengacu pada analisis kelemahan dan kekuatan perbankan syariah di Indonesia saat ini.

Adapun yang telah sampai kepada industri perbankan, dan tidak terkecuali perbankan syariah adalah perkembangan teknologi dan telekomunikasi dan salah satu aktifitas perbankan yang memanfaatkan teknologi tersebut adalah aplikasi EBangking atau Internet Bangking. Yang mana secara sederhana bisa diartikan sebagai aktifitas perbankan di internet. ${ }^{1}$

Mobile Banking merupakan salah satu jasa pelayanan perbankan yang disediakan oleh bang termasuk bank syariah agar nasabah dapat bertransaksi setiap saat, tanpa harus datang ke bank yang bersangkutan.

Mobile Banking bertujuan meningkatkan pelayanan kepada nasabah, memenuhi keinginan pasar, memberi kemudahan kepada nasabah untuk melakukan transaksi. Ada beberapa layanan yang digunakan nasabah dalam mobile banking antara lain untuk mengirim uang (transfer) antar rekening bank, untuk membayar tagihan telepon rumah, listrik, angsuran kredit rumah, mobil, motor, atau pinjaman apapun setiap bulan atau asuransi jiwa, asuransi mobil, dan transaksi nonfinansial lainnya. ${ }^{2}$

Dalam perbankan syariah tidak diperbolehkan mengandung unsur riba,

\footnotetext{
${ }^{1}$ Ismail, Perbankan Syariah (Jakarta: Prenada Media Group, 2011), 193.

${ }^{2}$ Ismail, Perbankan Syariah (Jakarta: Prenada Media Group, 2011),196.
}

sebagaimana firman Allah menjelaskan tentang larangan riba dalam Q.S AlImran [3]: 130 sebagai berikut.

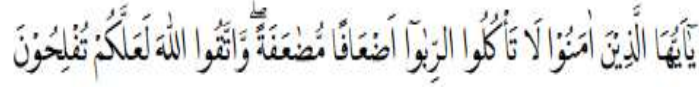

Terjemahnya:

Hai orang-orang yang beriman, janganlah kamu memakan riba dengan berlipat ganda dan bertakwalah kamu kepada Allah supaya kamu mendapat keberuntungan. ${ }^{3}$

Dalam kalangan mahasiswa mobile banking sangatlah bermanfaat terutama mahasiswa yang hidup diera globalisasi seperti sekarang ini yang menuntut mahasiswa melakukan aktifitasnya dengan cepat dan efisiensi. Mobile banking dapat memudahkan pembayaran spp mahasiswa sehingga tidak usah mengantri lama-lama. Namun penggunaan mobile banking kurang dimanfaatkan secara luas oleh mahasiswa hal ini dikarenakan kurangnya pengertian akan mobile banking maka dari itu Fakultas Ekonomi dan Bisnis Islam IAIN Palu yang memiliki jurusan yang berhubungan langsung dengan perbankan seharusnya tidak asing lagi dengan mobile banking, dan mahasiswa FEBI dituntut untuk menguasai salah satu jenis pelayanan tersebut karena perkembangan jaman dan dapat mengefisiensi waktu.

Mobile Banking dapat digunakan dalam beberapa jaringan provider seperti indosat, telkomsel, three, dan jaringan lainnya kecuali smartfren dan axis. Mobile banking adalah sebuah layanan perbankan yang dapat diakses oleh nasabah melalui telepon seluler

\footnotetext{
${ }^{3}$ Departemen Agama, Al-Qur'an Dan

Terjemahnya (Bekasi: Cipta Bagus Segara, 2015),
} 
(handphone) dengan menggunakan menu yang sudah tersedia di SIM (Subcriber Identity Module) Card. ${ }^{4}$

Jika dilihat dari aktivitas

financial yang dilakukan, layanan mobile banking lebih banyak digunakan untuk mencari informasi. Bahkan, jumlah aktivitas pencarian informasi bisa tiga kali lipat dibandingkan dengan kegiatan transaksi. Hal ini dikarenakan karakter masyarakat Indonesia yang masih belum percaya akan transaksi menggunakan mobile banking, selain itu juga kepercayaan nasabah terhadap resiko keamanan dalam menggunakan mobile banking, masih kurang sehingga menimbulkan kekhawatiran akan terkena penipuan masih tinggi. Ini salah satu sebab pertumbuhan mobile banking cukup lambat. $^{5}$

Berdasarkan hasil wawancara dari salah satu karyawan Bank MEGA Syariah di Kota Palu, mobile banking yaitu layanan yang memungkinkan nasabah untuk melakukan transaksi perbankan melalui telepon seluler atau internet. Mega Syariah Mobile pada Bank MEGA Syariah, nasabah bisa melakukan aktivasi aplikasi Mega Syariah Mobile sendiri dirumah atau dimanapun, dan tidak perlu melakukan aktivasi melalui customer service. Setiap ingin membuka tampilan aplikasi Mega Syariah Mobile maka nasabah

4 Yandi Wibowo. Analisis Tingkat Kesuksesan Menggunakan Mobile Banking Dengan Menggunakan Metode Respesifikasi Model Delone Dan Mclean. (Skripsi Akuntansi, Surakarta, 2011). 56.

Nurdin, Indah Musyawarah, Nurfitriani, Abdul Jalil (2020). Pengaruh Pelayanan Mobile Banking Terhadap Kepuasan Nasabah (Studi Pada Mahasiswa Perbankan Syariah IAIN Palu). Jurnal Ilmu Perbankan dan Keuangan Syariah, 2(1), 87-104. diminta untuk memasukkan nomor pin, maupun setiap melakukan transaksi nasabah harus memasukkan nomor pin, dan aplikasi Mega Syariah Mobile dapat secara otomatis terkunci sendiri setelah beberapa detik tidak digunakan atau kita minizise dilayar telepon seluler. Jadi keamanan pada Mega Syariah Mobile sudah terjamin. Setiap pengecekan saldo dengan menggunakan aplikasi Mega Syariah Mobile tidak dikenakan biaya, dan penampilan saldonya pun sudah otomatis dilayar aplikasi beranda Mega Syariah Mobile, jadi nasabah tidak perlu lagi untuk melakukan cek saldo.

\section{TINJAUAN PUSTAKA \\ 2.1 Pengertian Mobile Banking}

Mobile Banking adalah salah satu jasa pelayanan perbankan yang disediakan oleh bank termasuk bank syariah agar nasabah dapat bertransaksi setiap saat, tanpa harus datang ke bank yang bersangkutan. Mobile banking merupakan salah satu layanan perbankan yang menggunakan teknologi maju, layanan ini berbasis teknologi seluler yang memberikan kemudahan dalam melakukan kegiatan transaksi perbankan.

Mobile Banking adalah layanan melalui saluran distribusi elektronik bank untuk mengakses rekening yang dimiliki nasabah melalui SMS atau jaringan komunikasi lainnya dengan sarana telepon seluler atau komputer tablet. ${ }^{6}$.Mobile Banking merupakan

${ }^{6}$ Nurdin, N., Musyawarah, I., Nurfitriani, N., \& Jalil, A. (2020). Pengaruh Pelayanan Mobile Banking Terhadap Kepuasan Nasabah (Studi Pada Mahasiswa Perbankan Syariah IAIN Palu) Jurnal Ilmu Perbankan dan Keuangan Syariah, 2(2), 87-104. 
layanan yang memungkinkan nasabah bank untuk melakukan transaksi perbankan melalui ponsel atau smartphone. Layanan mobile banking dapat digunakan melalui menu yang sudah tersedia pada SIM Card, atau melalui aplikasi yang dapat diunduh dan diinstal oleh nasabah.

\subsection{Manfaat Mobile Banking}

Keberadaan layanan mobile banking tentu saja dapat memberikan berbagai manfaat dan kemudahan bagi penggunanya. Namun juga, nasabah dapat menggunakan layanan tersebut sesuai dengan kebutuhannya tanpa haru perlu repot datang ke bank. Nasabah dapat memanfaatkan layanan mobile banking dengan cara mengakses menu yang telah tersedia pada SIM Card atau aplikasi yang terinstal di ponsel. ${ }^{7}$

Fitur - fitur layanan mobile banking yang telah disediakan oleh pihak bank antara lain layanan informasi (saldo, mutasi rekening, tagihan kartu kredit, suku bunga, dan lokasi cabang / ATM terdekat), dan layanan transaksi, seperti transfer, pembayaran tagihan (listrik, air, pajak, kartu kredit, asuransi. Internet, bpjs, zakat), pembelian (pulsa, tiket), dan berbagai fitur lainnya.

Mobile banking bertujuan
meningkatkan pelayanan nasabah, memenuhi keinginan pasar, memberi kemudahan kepada nasabah untuk melakukan transaksi. Ada

\footnotetext{
${ }^{7}$ David Kurniawan dan Hatane Samuel. Analisis Penerimaan Nasabah Terhadap Layanan Mobile Banking Dengan Menggunakan Pendekatan Technology Acceptance Model dan Theory Of Reasoned Action. (Jurnal Manajemen Pemasaran, 2013) Vol. 1. No.1. 13.
}

beberapa layanan yang digunakan nasabah dalam mobile banking antara lain untuk mengirim uang (transfer) antar rekening bank, untuk membayar tagihan telepon rumah, listrik, angsuran kredit rumah, mobil, motor, atau pinjaman apapun setiap bulan atau asuransi jiwa, asuransi mobil, dan transaksi nonfinansial lainnya. ${ }^{8}$

\subsection{Pengertian Minat}

Minat yaitu kecenderungan tertarik pada sesuatu yang relatif tetap untuk lebih memperhatikan dan mengingat secara terus menerus yang diikuti rasa senang untuk memperoleh kepuasan dalam mencapai kepuasan penggunaan teknologi.Indikator untuk mengetahui minat nasabah menggunakan layanan mobile banking yaitu keinginan. Seseorang menggunakan teknologi tersebut dan akan terus menggunakannya untuk masa depan. ${ }^{9}$ Terdapat beberapa indikator tentang minat yaitu sebagai berikut :

a. Minat transaksional, yaitu kecenderungan untuk membeli atau menggunakan suatu produk.

b. Minat refensial, yaitu kecenderungan seseorang untuk merefrensikan produk kepada orang lain.

c. Minat Eksploratif, yaitu minat yang menggambarkan perilaku seseorang mencari informasi mengenai suatu produk yang diminatinya dan

\footnotetext{
Pelayanan Terhadap Kepuasan Nasabah Pada Bank DKI Syariah. (Jakarta: UIN Syarif Hidayatullah, 2008). 56.

${ }^{9}$ Dwi Mastia Harlan, Pengaruh Kemudahan Penggunaan, Kepercayaan, dan Resiko Terhadap Minat Bertransaksi Menggunakan E-Banking. (Skripsi, Akuntansi, Yogyakarta, 2014).43.
}

${ }^{8}$ Badi'u Rajab. Pengaruh Kualitas 
mencari informasi untuk mendukung sifat-sifat positif dari produk tersebut. $^{10}$

Minat Seseorang terhadap suatu objek akan lebih kelihatan apabila objek tersebut sesuai sasaran dan berkaitan dengan keinginan dan kebutuhan seseorang yang bersangkutan. Dalam kamus umum bahasa Indonesia, minat diartikan sebagai sebuah kesukaan (kecenderungan hati) kepada suatu perhatian atau keinginan. ${ }^{11}$

Menurut Komarudin Minat Nasabah adalah suatu rasa lebih suka dan rasa ketertarikan pada suatu proses pengambilan keputusan yang dilakukan oleh konsumen. Ada beberapa tahap dalam proses pengambilan keputusan yang umumnya dilakukan oleh seseorang yaitu pengenalan kebutuhan dan proses informasi konsumen. ${ }^{12}$

\subsubsection{Faktor yang mempengaruhi timbulnya minat \\ Ada beberapa faktor yang mempengaruhi minat, yaitu: ${ }^{13}$}

a. Perbedaan pekerjaan artinya dengan adanya perbedaan pekerjaan seseorang dapat memperkirakan minat terhadap tingkat pekerjaan yang ingin dicapainya, aktivitas yang dilakukan, penggunaan waktu senggangnya, dan lain-lain.

10 Esthi Dwityanti, "Analisis Faktor-

Faktor Yang Mempengaruhi Minat Beli Konsumen Terhadap Layanan Internet Banking Mandiri'" ( Tesis, Universitas Diponegoro, Semarang, 2008), 20.

11 . Kamus Pusat Pembinaan Dan Pengembangan Bahasa. Kamus Besar Bahasa Indonesia. (Jakarta, 2011).

${ }^{12}$ Komarudin, Kamus Perbankan, (Jakarta: Grafindo, 1994), 94.

${ }^{13}$ Malayu Hasibuan, Dasar-dasar Perbankan, (Jakarta: Bumi Aksara, 2008), 205. b. Perbedaan sosial ekonomi artinya seseorang mempunyai sosial ekonomi tinggi akan lebih mudah mencapai apa yang diinginkannya dari pada yang mempunyai sosial ekonomi rendah.

c. Perbedaan hobi atau kegemaran artinya bagaimana seseorang menggunakan waktu senggangnya.

d. Perbedaan jenis kelamin artinya minat wanita dengan pria akan berbeda, misalnya pada pola berbelanja.

e. Perbedaan usia, artinya setiap usia memiliki minat yang berbeda terhadap suatu barang atau aktivitas lainnya.

\subsection{Manfaat}

Manfaat yaitu tingkat dimana seseorang berfikir bahwa menggunakan suatu sistem akan meningkatkan kinerjanya. Manfaat yang diyakini individu dapat diperoleh apabila menggunakan teknologi informasi. ${ }^{14}$ Persepsi terhadap manfaat adalah yang diyakini individu dapat diperolehnya apabila menggunakan teknologi informasi.

Beberapa indikator kemanfaatan penggunaan teknologi informasi yang meliputi yaitu sebagai berikut:

a. Mokes Job Easir ( menjadi lebih mudah ), transaksi perbankan menjadi lebih mudah.

b. Increase Productivity ( menambah produktifitas ), dapat meningkatkan pengetahuan dan kinerja pengguna.

${ }^{14}$ Davis, "Preived Usefulnes, Perceived Ease OF Use, And User Acceptance Of Information Tecnology', Jurnal Management Information System (Online) Vol. 13. No. 3, 1989. 320 . 
c. Enchance effectiveness ( mempertinggi efektifitas ), dapat mempercepat waktu pengguna dalam penelusuran.

d. Mempengaruhi tingkat kinerja seseorang yang menggunakannya. ${ }^{15}$

Berdasarkan definisi tersebut dapat diartikan bahwa manfaat dari penggunaan mobile banking dapat meningkatkan kinerja dan kinerja orang yang menggunakannya.Kemanfaatan dalam mobile banking merupakan manfaat yang diperoleh atau diharapkan oleh para nasabah dalam melaksanakan tugas pekerjaannya, karenanya, tingkat kemanfaatan mobile banking mempengaruhi sikap para nasabah terhadap sistem tersebut. ${ }^{16}$

\section{$2.5 \quad$ Kepercayaan}

Kepercayaan adalah suatu keyakinan dari pihak tertentu terhadap pihak lain dalam hubungan antara kedua belah pihak berdasarkan keyakinan bahwa pihak yang dipercayakan akan memenuhi segala kewajiban sesuai yang diharapkan. ${ }^{17}$ Dalam hal penggunaan mobile banking, kebanyakan pengguna tidak memahami betul resiko keamanan dan kerahasiaan dari mobile banking, mereka hanya beranggapan bahwa pihak bank telah

15 Nurdin, N., Azizah, W. N., \& Rusli, R. (2020). Pengaruh Pengetahuan,Kemudahan dan Risiko Terhadap Minat Bertransaksi Menggunakan Finansial Technology (Fintech) Pada Mahasiswa Institut Agama Islam Negeri (IAIN) Palu Jurnal Ilmu Perbankan dan Keuangan Syariah, 2(2), 199-222.

16 Dwi Mastia Harlan, "Pengaruh Kemudahan Penggunaan, Kepercayaan, dan Resiko Terhadap Minat Bertransaksi menggunakan E-Banking',(Skripsi, Akuntansi, Yogyakarta,2014), 43.

${ }^{17}$ Ibid, 44. memperhatikan keamanan dan kerahasiaan, padahal pengguna tidak mengetahui seberapa kuatnya keamanan dan kerahasiaan dari mobile banking. Oleh karena itu, kepercayaan nasabah merupakan faktor penting yang mendorong nasabah untuk bertransaksi perbankan. Terdapat beberapa indikator kepercayaan yaitu sebagai berikut : ${ }^{18}$

a. Kehandalan, artinya kemampuan memberikan pelayanan yang dijanjikan kepada nasabah dengan segera, akurat, dan memuaskan.

b. Kepedulian, merupakan sikap empati yang tinggi yang dapat dirasakan pihak bank mampu memberikan solusi permasalahan nasabahnya.

c. Kredibilitas, artinya penyelenggaraan mekanisme operasional transaksi elektronik perbankan yang jujur dan dapat dipercaya.

Kepercayaan dalam Konsep Islam, telah disebutkan dalam Q.S An-Nisa ayat[4]: 58 yaitu:

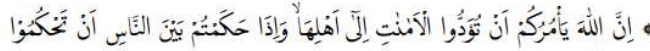

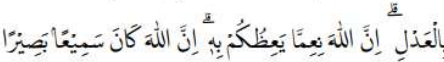

Terjemahnya:

Sesungguhnya Allah menyuruhmu menyampaikan amanat kepada yang berhak menerimanya, dan apabila kamu menetapkan hukum di antara manusia hendaknya kamu menetapkannya dengan adil. Sungguh, Allah sebaik-baik yang memberi pengajaran kepadamu. Sungguh, Allah Maha Mendengar, Maha Melihat.
18 Junai Al Fian, "Pengaruh Kepuasan dan Kepercayaan Pelanggan Terhadap Loyalitas Pelanggan Auto 2000 Sungkono Surabaya', Jurnal Ilmu dan Riset Manajemen Vol. 5, No.6, 2016, 4. 
Sesungguhnya

memerintahkan kalian untuk menunaikan amanat yang berbeda beda yang kalian dipercaya untuk menyampaikan kepada para pemiliknya, maka janganlah kalian melalaikan amanat - amanat itu. Dan dia memerintahkan kalian untuk memutuskan perkara diantara manusia dengan dasar keadilan dan obyektif, bila kalian memutuskan permasalahan diantara mereka. Dan itu adalah sebaik baik nasihat yang Allah sampaikan kepada kalian dan memberi petunjuk kalian kepadanya. Sesungguhnya Allah Maha Mendengar ucapan - ucapan kalian, meneliti seluruh perbuatan kalian lagi Maha Melihatnya. ${ }^{19}$

Ayat ini bersifat umum, sehingga amanah itu diartikan sebagai kepercayaan. Dalam semua proses bisnis, kepercayaan merupakan kunci utama dalam segala bentuk bisnis baik dalam lingkungan online maupun offline. Kepercayaan dibangun dengan kenal dan saling mengenal secara baik, ada proses ijab-qabul, ada materai, dan lain sebagainya. Para pelaku bisnis selain itu diproteksi pula secara horizontal oleh hukum-hukum disamping proteksi secara vertical seperti norma, nilai, dan etika yang dianut oleh para pelaku bisnis. Dalam dunia online demikian pula, harmonisasi antara ketiga aspek di atas dipadukan dengan mekanismemekanisme pembangun kepercayaan secara total dalam proses keseluruhan. ${ }^{20}$

${ }^{19}$ Salim Bahreisy \& Said Bahreisy,

Terjemah Singkat Tafsir Ibnu Katsier Cet.1

(Surabaya: PT Bina Ilmu, 1988), 134.

20 Ono W Purbo dalam Muhammad,

Etika Bisnis Islam,(Yogyakarta: Unit Penerbit dan Percetakan Akademi Manajemen Perusahaan YKPN, 2004). 224.

\subsection{Kemudahan Penggunaan}

Kemudahan

Penggunaan merupakan sebagai tingkat dimana seseorang meyakini bahwa penggunaan teknologi informasi merupakan hal yang mudah dan tidak memerlukan usaha yang keras bagi penggunanya. Ada beberapa indikator kemudahan penggunaan teknologi informasi antara lain yaitu teknologi informasi sangat mudah dipelajari, teknologi informasi mengerjakan dengan mudah apa yang inginkan penggunanya, keterampilan pengguna akan bertambah ketika menggunakan teknologi informasi, dan teknologi informasi sangat mudah dioperasikan. $^{21}$

Kemudahan

penggunaan merupakan salah satu prinsip penting dalam Islam. Kemudahan merupakan anugerah dari Allah SWT, diberikan agar manusia tetap bersemangat dan tekun dalam menjalankan ajaran agama, terutama dalam keadaan sulit. Kemudahan- kemudahan yang diberikan Islam adalah kemudahan yang paling sempurna. Betapa bahagianya menjadi seorang muslim karena segala sesuatunya adalah kebaikan. Agama Islam selalu memberikan keringanan bagi setiap muslim Allah SWT berfirman dalam Q.S Al- Baqarah [2]: 185:

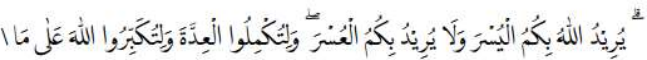

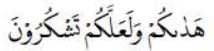

Terjemahnya:

${ }^{21}$ Davis, "Preived Usefulnes, Perceived Ease OF Use, And User Acceptance Of Information Tecnology', Jurnal Management Information System (Online) Vol. 13. No. 3. 1989. 318 . 
Allah menghendaki kemudahan bagimu, dan tidak menghendaki kesukaran bagimu. Hendaklah kamu mencukupkan bilangannya dan mengagungkan Allah atas petunjuk-Nya yang diberikan kepadamu, agar kamu bersyukur.

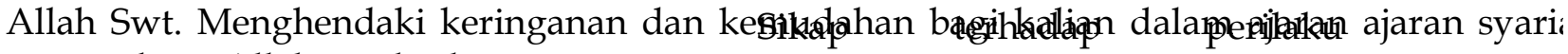
mengagungkan Allah pada hari raya Idul Fitri, serta supaya kalian mengagungkan Nya atas hidayah Nya kepada kalian, dan agar kalian mensyukuri atas kenikmatan Nya yang tercurah pada kalian berupa hidayah taufik dan kemudahan. ${ }^{22}$

Pengertian kemudahan penggunaan m-banking didefinisikan sebagai tingkat dimana seseorang meyakini bahwa penggunaan m-banking merupakan hal yang mudah dan tidak memerlukan usaha keras dari pemakainya. Konsep ini mencakup kejelasan tujuan penggunaan m-banking dan kemudahan penggunaan sistem untuk tujuan sesuai dengan keinginan pemakai.

Terdapat beberapa indikator kemudahan penggunaan teknologi informasi antara lain meliputi: ${ }^{23}$

a. Teknologi informasi sangat mudah dipelajari.

b. Teknologi informasi mengerjakan dengan mudah apa yang diinginkan oleh pengguna.

c. Keterampilan pengguna akan bertambah dengan menggunakan teknologi

d. informasi.

${ }^{22}$ Salim Bahreisy \& Said Bahreisy, Terjemah Singkat Tafsir Ibnu Katsier Cet.1 (Surabaya: PT Bina Ilmu, 1988), 34.

23 Bastian Amanullah, Pengaruh Persepsi Manfaat, Kemudahan penggunaan, dan kepercayaan terhadap sikap positif penggunaan layanan mobile banking. Skripsi, Fakultas Ekonomi dan Bisnis, Universitas Diponegoro, 2014. 25. e. Teknologi informasi sangat mudah untuk dioperasikan.

\subsection{Sikap positif penggunaan pada layanan mobile banking}

merupakan perasaan positif atau negatif seseorang untuk melakukan perilaku tersebut.Sikap seseorang juga dapat dilihat dari kepercayaan seseorang untuk mau menggunakan sebuah sistem.Dalam menggunakan layanan mobile banking kepercayaan pengguna mobile banking dapat ditunjukkan melalui persepsi kegunaan maupun persepsi kemudahan penggunaan.Apabila sebuah teknologi sistem infomasi dirasa menguntungkan bagi penggunanya, perasaan positif yang timbul juga semakin besar.

Dalam penelitian ini, perasaan positif pengguna mobile banking ditunjukkan oleh perasaan suka seseorang terhadap keuntungan yang diberikan mobile banking.Menurut Philip Kotler dan Keller sikap yaitu evaluasi dalam waktu lama tentang yang disukai atau tidak disukai oleh seseorang, perasaan emosional, dan kecenderungan tindakan terhadap objek atau ide.Sikap merupakan perasaan positif ataupun negatif.Sikap penggunaan dikonsepkan sebagai sikap terhadap penggunaan sistem yang berbentuk penerimaan atau penolakan sebagai akibat dari seseorang yang menggunakan suatu teknologi dalam pekerjaannya. ${ }^{24}$

24 Bastian Amanullah, Pengaruh Persepsi Manfaat, Kemudahan Penggunaan, dan Kepercayaan Terhadap Sikap Positif 


\section{METHODOLOGY}

Penelitian ini menggunakan pendekatan kuantitatif..25,26 Penelitian kuantitatif dilakukan dengan mengumpulkan data yang berupa angka, atau data berupa kata-kata atau kalimat yang dikonversi menjadi data yang berbentuk angka. Data yang berupa angka tersebut kemudian diolah dan dianalisis untuk mendapatkan suatu informasi ilmiah dibalik angka-angka tersebut. ${ }^{27}$

Adapun lokasi penelitian adalah pada PT Bank MEGA Syariah Kota Palu Provinsi Sulawesi Tengah yang beralamat dijalan Jenderal Sudirman, Besusu Barat, Kecamatan Palu Timur, Kota Palu, Sulawesi tengah.

Populasi dalam penelitian adalah Nasabah Bank MEGA Syariah. Dimana hal ini populasinya berjumlah 164 jiwa. ${ }^{28}$ Jumlah populasi diambil dari jumlah nasabah yang menggunakan mobile banking di Bank MEGA Syariah.

Kemudian untuk menentukan besarnya sampel, peneliti menggunakan

Penggunaan Layanan Mobile Banking. (Skripsi Manajemen, Semarang, 2014). 19.

25 Nurdin, N. (2018). Institutional Arrangements in E-Government Implementation and Use: A Case Study From Indonesian Local Government. International Journal of Electronic Government Research (IJEGR), 14(2), 44-63. doi: 10.4018/ijegr.2018040104

26 Nurdin, N., Stockdale, R., \& Scheepers, H. (2014). Coordination and Cooperation in E-Government: An Indonesian Local E-Government Case The Electronic Journal of Information Systems in developing Countries, 61(3), 1-21.

27 Nanang Martono, Metode Penelitian Kuantitatif, Edisi revisi 2, (Cet. V ; Jakarta : PT. Rajagrafindo Persada, 2016), 20.

\footnotetext{
${ }^{28}$ Dicky Prayuda, wawancara dengan penulis, Bank Mega Syariah Kota Palu, Palu, 8 Juni
}

rumus dengan Metode Slovin. ${ }^{29}$ Diketahui $\mathrm{N}=164$ jiwa, dengan tingkat kesalahan pengambilan sampel $10 \%$.

$$
\begin{aligned}
& \mathbf{n}=\frac{\mathbf{N}}{\left(\mathbf{1}+\boldsymbol{N}(\mathbf{e})^{2)}\right.} \\
& \mathbf{n}=\frac{164}{(1+164(10 \%) 2)}=\frac{164}{1+1,64}=\frac{164}{2,64}=62,12
\end{aligned}
$$

Berdasarkan hasil dari rumus tersebut maka diperoleh sampel dalam penelitian ini sebanyak 62 jiwa yang merupakan Nasabah Bank MEGA Syariah.

Teknik analisa data pada penelitian ini menggunakan analisa kuantitatif. Dimana analisa kuantitatif ini merupakan proses analisa yang terdapat data-data berbentuk angka dengan cara perhitungan secara statistik untuk mengukur pengaruh manfaat, kepercayaan, dan kemudahan penggunaan terhadap minat nasabah menggunakan mobile banking di Bank MEGA Syariah Cabang Palu. Analisa data dilakukan melalui tahap uji validitas, reabilitas, uji regresi berganda, dan uji asumsi klasik. Untuk pembuktian hipotesis penulis menggunakan uji f dan uji t. ${ }^{30}$

\section{HASIL DAN PEMBAHASAN}

\subsection{Deskripsi Umum Subjek Penelitian}

29 Muhammad, Metode Penelitian Ekonomi Islam Pendekatan Kuantitatif, (Cet. 1, Jakarta : Rajawali Pers, 2008), 180.

30 Abdul Jalil . Pengaruh Beban Kerja, Stres Kerja dan Lingkungan Kerja Terhadap Kinerja Guru Madrasah Aliyah Negeri 2 Kota Palu. Jurnal Ilmu Perbankan dan Keuangan Syariah, 1(2), 117134. 2019 
Penelitian ini dilakukan pada nasabah yang ada di Bank MEGA Syariah. Data penelitian menggunakan instrument kuesioner yang dibagikan kepada nasabah di Bank MEGA Syariah sebagai sampel penelitian. Proses penyebaran kuesioner ini disebarkan oleh peneliti kepada sampel yang diteliti dengan perincian seperti dalam tabel berikut ini.

Tabel 1

Deskripsi Kuesioner

Sumber: Data Primer, 2020

Pada tabel diatas dijelaskan bahwa jumlah sampel yang digunakan adalah sebanyak 62 orang

Tabel 2

Deskripsi Responden

\begin{tabular}{|c|c|c|}
\hline $\begin{array}{c}\text { Jenis } \\
\text { Kelamin }\end{array}$ & Responden & Persentase \\
\hline Laki-laki & 21 & $33,87 \%$ \\
\hline Perempuan & 41 & $66,13 \%$ \\
\hline Jumlah & 62 & $100 \%$ \\
\hline
\end{tabular}

Sumber : Data Primer, 2020

Pada tabel diatas menunjukkan bahwa responden atau sampel yang berjumlah 62 orang dalam penelitian ini terbagi atas yang berjenis kelamin lakilaki berjumlah 21 orang (34\%) sedangkan yang berjenis kelamin perempuan berjumlah 41orang (66\%), sehingga terlihat bahwa sampel penelitian didominasi oleh responden yang berjenis kelamin perempuan.

\subsection{Uji Validitas dan Reliabilitas}

\subsubsection{Uji Validitas}

Uji Validitas menggunakan instrumen pada setiap penelitian, maka terlebih dahulu seorang peneliti harus mengetahui apakah instrument yang digunakan valid atau tidak, karena

\begin{tabular}{|c|c|c|c|c|}
\hline $\begin{array}{c}\text { Jumlah } \\
\text { Sampel }\end{array}$ & $\begin{array}{c}\text { Kuesioner } \\
\text { Disebar }\end{array}$ & $\begin{array}{c}\text { Kuesioner } \\
\text { Kembali }\end{array}$ & $\begin{array}{c}\text { Kuesioner } \\
\text { Diolah }\end{array}$ & Persentase \\
\hline 62 & $\begin{array}{c}62 \\
\text { rangkap }\end{array}$ & $\begin{array}{c}62 \\
\text { rangkap }\end{array}$ & $\begin{array}{c}62 \\
\text { rangkap }\end{array}$ & $100 \%$ \\
\hline
\end{tabular}

sebuah instrumen apabila tidak valid maka data tersebut tidak dapat digunakan. Pada penelitian ini disetiap pernyataannya untuk dilihat apakah valid atau tidaknya, dapat diketahui dari kolom Corrected Item Total Correction atau r Hitung, dan Uji signifikansi dilakukan dengan membandingkan nilai $r$ hitung dengan $r$ tabel untuk degree of freedom $(\mathrm{df})=\mathrm{n}-2$, dimana $\mathrm{n}$ merupakan jumlah sampel pada penelitian. Pada penelitian ini jumlah sampel yang dipakai adalah 62 sampel dan besarnya df dapat dihitung $\mathrm{df}=\quad 62-2=60 \quad$ dan alpha(signifikansi) 0,05 didapat $r$ tabel 0,1986. Jika $r$ hitung lebih besar dari $r$ tabel dan nilai positif maka indicator dinyatakan valid. ${ }^{31}$

\begin{tabular}{|c|c|c|c|c|c|}
\hline Variabel & $\begin{array}{c}\text { Item } \\
\text { Pernyataan }\end{array}$ & $\begin{array}{l}\text { Corrected } \\
\text { Item Total } \\
\text { Correlation } \\
\text { (R Hitung) }\end{array}$ & \begin{tabular}{|l}
$\mathrm{R}$ \\
Tabel
\end{tabular} & $\begin{array}{c}\text { Taraf } \\
\text { Sig } \\
(0.05)\end{array}$ & Keterangan \\
\hline \multirow{5}{*}{ Manfaat $\left(\mathrm{X}_{1}\right)$} & 1 & 0.643 & \begin{tabular}{|l|l|}
0.1986 \\
\end{tabular} & 0.000 & Valid \\
\hline & 2 & 0.335 & 0.1986 & 0.008 & Valid \\
\hline & 3 & 0.503 & 0.1986 & 0.000 & Valid \\
\hline & 4 & 0.422 & 0.1986 & 0.001 & Valid \\
\hline & 5 & 0.571 & 0.1986 & 0.000 & Valid \\
\hline \multirow{5}{*}{$\begin{array}{c}\text { Kepercayaan } \\
\left(\mathrm{X}_{2}\right)\end{array}$} & 1 & 0.769 & 0.1986 & 0.000 & Valid \\
\hline & 2 & 0.367 & 0.1986 & 0.003 & Valid \\
\hline & 3 & 0.636 & 0.1986 & 0.000 & Valid \\
\hline & 4 & 0.670 & 0.1986 & 0.000 & Valid \\
\hline & 5 & 0.636 & 0.1986 & 0.000 & Valid \\
\hline \multirow{5}{*}{$\begin{array}{l}\text { Kemudahan } \\
\text { Penggunaan } \\
\left(X_{3}\right)\end{array}$} & 1 & 0.769 & 0.1986 & 0.000 & Valid \\
\hline & 2 & 0.367 & 0.1986 & 0.003 & Valid \\
\hline & 3 & 0.636 & 0.1986 & 0.000 & Valid \\
\hline & 4 & 0.670 & 0.1986 & 0.000 & Valid \\
\hline & 5 & 0.636 & 0.1986 & 0.000 & Valid \\
\hline
\end{tabular}

31 Imam Ghozali, “Aplikasi Analisis Multivariate dengan Program IBM SPSS 23" (Cet.I; Semarang: Universitas Diponegoro, 2013), 53. 


\begin{tabular}{|c|l|l|l|l|l|}
\hline & 1 & 0.475 & 0.1986 & 0.000 & Valid \\
& 2 & 0.480 & 0.1986 & 0.000 & Valid \\
Minat & 3 & 0.472 & 0.1986 & 0.000 & Valid \\
Nasabah & 4 & 0.695 & 0.1986 & 0.000 & Valid \\
Menggunakan & 5 & 0.428 & 0.1986 & 0.001 & Valid \\
Mobile & 6 & 0.657 & 0.1986 & 0.000 & Valid \\
Banking (Y) & 7 & 0.461 & 0.1986 & 0.000 & Valid \\
& 8 & 0.389 & 0.1986 & 0.002 & Valid \\
& 9 & 0.518 & 0.1986 & 0.000 & Valid \\
& & & & & \\
\hline
\end{tabular}

Berdasarkan tabel di atas menjelaskan bahwa, dari nilai $\mathrm{r}_{\text {hitung }}$ pada kolom Corrected Item Total Correlation, dimana masing-masing variabel menunjukkan semua pernyataan valid karena $\mathrm{r}_{\text {hitung }}$ lebih besar dan positif dari $r_{\text {tabel. }}$

\subsubsection{Uji Reliabilitas}

Uji Reliabilitas merupakan uji data yang diperoleh sebagai misal hasil dari jawaban kueisioner yang telah dibagikan.Jika kuesioner tersebut itu reliable, andai kata jawaban responden tersebut konsisten dari waktu ke waktu.Uji reliabilitas diuji terhadap seluruh pertanyaan pada penelitian ini dan menggunakan program SPSS dengan uji statistic Croncbach Alpha (a). Suatu variabel dikatakan reliabel jika memberikan nilai $>0,60 .{ }^{32}$

Tabel 4 Uji Reliabilitas

Sumber : Data Primer, 2020

Tabel di atas menunjukkan, bahwa dari hasil uji data dengan Croncbach alphamasing-masing variabel diatas baik variabel $X_{1}, X_{2}, X_{3}$ maupun $Y$ kesemuanya memiliki nilai yang reliabel yaitu lebih dari 0,60 . Dengan demikian pengelolaan data dapat dilanjutkan ke jenjang berikutnya.

\subsection{Uji Simultan (Uji F)}

Berdasarkan hasil uji Anova (Analysis of varians) atau $\mathrm{F}$ test

\footnotetext{
${ }^{32}$ Ibid, 48
}

diketahui bahwa nilai signifikansi untuk pengaruh manfaat, kepercayaan, dan kemudahan penggunaan secara simultan terhadap minat sebesar $0.000<0.05$ dan nilai $F_{\text {hitung }} 9.754>\mathrm{F}_{\text {Tabel }}$ yaitu 2.70, dapat dikatakan bahwa $\mathrm{H}_{4}$ secara bersama-sama signifikan mempengaruhi minat nasabah menggunakan mobile banking.

\subsection{Uji Parsial (Uji t)}

Berdasarkan hasil perhitungan statistic di atas, uji $\mathrm{t}$ dari 3 variabel $X$ apabila dimasukkan dalam regresi terlihat:

1. Diketahui Manfaat $\left(\mathrm{X}_{1}\right)$ diperoleh $t_{\text {thitung }} 1.378<$ t tabel 1.988 dan nilai signifikansi (sig) 0.174 lebih besar dari nilai a 0.05 . artinya $0.174>0.05$, dapat dikatakan bahwa manfaat tidak signifikan mempengaruhi minat nasabah menggunakan mobile banking.

2. Diketahui Kepercayaan $\left(X_{2}\right)$ diperoleh $t_{\text {hitung }} 2.208>t_{\text {tabel }} 1,988$ dan nilai signifikansi (sig) 0.031 lebih besar dari nilai a 0.05 . artinya $0.031>$ 0.05, dapat dikatakan bahwa

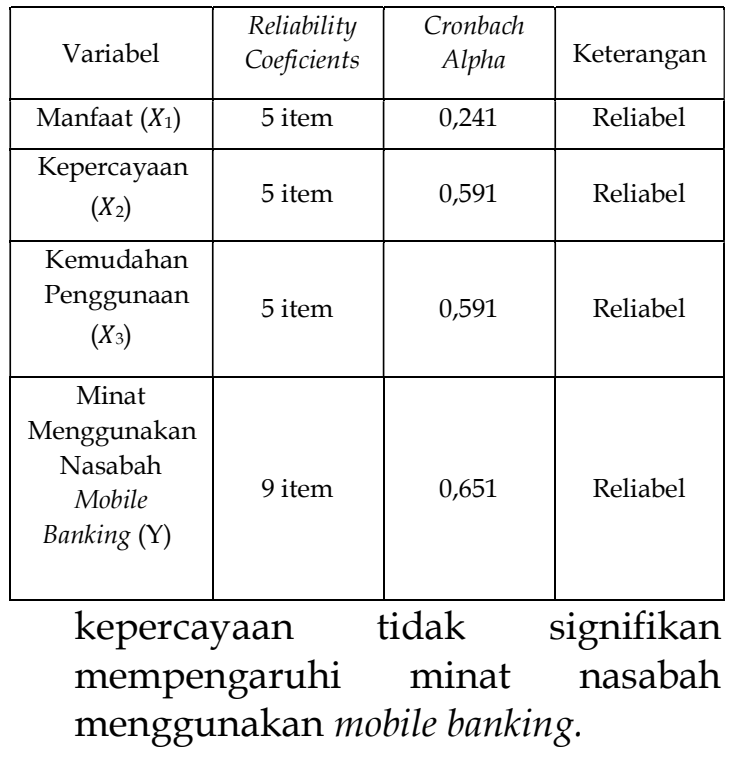


3. Diketahui Kemudahan Penggunaan $\left(X_{3}\right)$ diperoleh $t_{\text {hitung }} 1.785<t_{\text {tabel }} 1,988$ dan nilai signifikansi (sig) 0.079 lebih besar dari nilai a 0.05 . artinya 0.079 $>0.05$, dapat dikatakan bahwa kemudahan penggunaan tidak signifikan mempengaruhi minat nasabah menggunakan mobile banking.

\subsection{Uji Analisis Regresi Linier Berganda}

Berdasarkan tabel uji data regresi di atas, maka bentuk persamaan regresi dari model tersebut adalah sebagai berikut:

$$
\begin{aligned}
& Y=\beta o+\beta_{1} X_{1}+\beta_{2} X_{2}+\beta_{3} X_{3}+e \\
& =8.660+0.473 X_{1}+0.570 X_{2}+0.494 X_{3}+e
\end{aligned}
$$

Dari persamaan di atas menunjukkan bahwa ketiga variabel (Manfaat, Kepercayaan dan Kemudahan Penggunaan) memiliki arah positif terhadap variabel dependen (minat nasabah menggunakan mobile banking ). Hasil

perhitungan di atas, dijelaskan dengan sebagai berikut:

1. Nilai Konstanta (a) sebesar 8.660 ini diartikan jika variabel independen yaitu Manfaat, Kepercayaan dan Kemudahan Penggunaan diasumsikan bernilai 0, maka keputusan minat akan menurun sebesar 8.660

2. Nilai koefisien regresi Manfaat $\left(X_{1}\right)$ sebesar 0.473 dan bernilai positif. Meskipun bernilai positif atau hubungannya positif namun variable manfaat tidak signifikan menumbuhkan minat nasabah menggunakan mobile banking.
3. Nilai koefisien regresi Kepercayaan $\left(\mathrm{X}_{2}\right)$ sebesar 0.570 dan bernilai positif - Meskipun bernilai positif atau hubungannya positif namun variable kepercayaan tidak signifikan menumbuhkan minat nasabah menggunakan mobile banking.

4. Nilai koefisien regresi Kemudahan Penggunaan $\left(\mathrm{X}_{3}\right)$ sebesar 0.494 dan bernilai positif . Meskipun bernilai positif atau hubungannya positif namun variable kemudahan penggunaan tidak signifikan menumbuhkan minat nasabah menggunakan mobile banking.

\subsection{Pembahasan Hasil Penelitian \\ 4.6.1 Pengaruh Manfaat $\left(X_{1}\right)$, Terhadap Minat Nasabah Menggunakan Mobile Banking.}

Pengaruh Manfaat yaitu tingkat dimana seseorang berfikir bahwa menggunakan suatu sistem akan meningkatkan kinerjanya. Manfaat yang diyakini individu dapat diperoleh apabila menggunakan teknologi informasi. ${ }^{33}$ Persepsi terhadap manfaat adalah yang diyakini individu dapat diperolehnya apabila menggunakan teknologi informasi.berdasarkan pengujian perbandingan $\mathrm{F}_{\text {hitung }}>\mathrm{F}_{\text {tabel }}$ yaitu sebesar $1.378<1.988$ dan nilai signifikansi sebesar $0.174>0.05$ dengan ini menunjukkan bahwa variabel Manfaat berpengaruh tidak signifikan

\footnotetext{
${ }^{33}$ Davis, "Preived Userfulnes,
} Perceived Ease Of Use, And User Acceptance Of Information Tecnology", Jurnal Management Information System (Online) Vol. 13, No. 3, 320. 
terhadap Minat Nasabah Menggunakan Mobile Banking.

Hal ini mengindikasikan bahwa manfaat yang dilakukan oleh pihak bank belum tercapai maksimal untuk menimbulkan minat nasabah.Hasil yang ditunjukkan dari kuesioner yang telah dibagikan walaupun banyak yang menyatakan positif dalam memberikan jawabannya, namun masih banyak responden yang menyatakan kurang setuju atau cenderung negatif atas jawaban yang diberikan.

$\begin{array}{ccr}\text { Walaupun } & \text { dari } & \text { mayoritas } \\ \text { menyatakan } & \text { berminat } & \text { untuk }\end{array}$
menggunakan mobile banking, namun hal tersebut tidak bisa disimpulkan bahwa variabel manfaat mempunyai pengaruh yang signifikan terhadap minat nasabah menggunakan mobile banking.

Hal ini dikarenakan semakin besar manfaat suatu teknologi, maka semakin besar pula minat seseorang untuk menggunakan teknologi tersebut, termasuk juga teknologi mobile banking. Manfaat mobile banking yang begitu besar untuk nasabah melakukan transaksi perbankan dimana mobile banking dapat mempersingkat waktu nasabah melakukan transaksi sehingga manfaat mobile banking dapat menarik minat nasabah untuk menggunakan mobile banking dan manfaat memiliki pengaruh positif terhadap minat nasabah untuk menggunakan mobile banking tersebut.

\subsubsection{Pengaruh Kepercayaan $\left(\mathrm{X}_{2}\right)$,}

Terhadap Minat Nasabah Menggunakan Mobile Banking.
Seiring maraknya kejahatan internet, keamanan dan kerahasiaan menjadi sangat dalam penggunaan internet banking ataupun mobile banking. Isu keamanan dan kerahasiaan menjadi isu yang paling diperhatikan oleh pengguna dalam penggunaan teknologi informasi.

Kebanyakan pengguna tidak memahami risiko keamana, dan kerahasiaan dari electronic banking. Pengguna beranggapan bahwa pihak bank telah memperhatikan keamanan dan kerahasiaan dari teknologi informasi layanan mobile banking, belum tentu sebuah bank besar, keamanan dan kerahasiaan data nasabah terjaga dengan baik.

Hasil dari uji variabel kepercayaan dengan minat nasabah menggunakan mobile banking menyatakan bahwa kepercayaan memiliki pengaruh positif terhadap minat nasabah menggunakan mobile banking. Hal tersebut ditunjukkan dengan hasil uji yaitu dengan hasil nilai $\mathrm{T}_{\text {hitung }}>\mathrm{T}_{\text {tabel }}$ dengan nilai sebesar 2.208 $>1.988$ dan nilai signifikan sebesar $0.031>0.05$ maka dapat disimpulkan bahwa variabel kepercayaan memiliki pengaruh tidak signifikan terhadap minat nasabah menggunakan mobile banking.

4.6.3 Pengaruh Kemudahan Penggunaan $\left(X_{3}\right)$, Terhadap Minat Nasabah Menggunakan Mobile Banking.

Konsep kemudahan penggunaan menunjukkan tingkat dimana seseorang meyakini bahwa penggunaan sistem informasi adalah mudah dan tidak memerlukan usaha keras dari pemakainya untuk bisa menggunakan. 
Konsep ini mencakup kejelasan tujuan penggunaan sistem informasi dan kemudahan penggunaan sistem untuk tujuan sesuai dengan keinginan pemakainya. Konsep ini memberikan pengertian bahwa apabila sistem informasi mudah digunakan, maka pengguna cenderung untuk menggunakan informasi tersebut.

Hasil uji antara kemudahan penggunaan dengan minat nasabah menggunakan mobile banking menyatakan bahwa kemudahan penggunaan berpengaruh negatif terhadap minat nasabah menggunakan mobile banking. Hal Tersebut ditunjukkan denga hasil uji yaitu nilai $\mathrm{T}_{\text {hitung }}<\mathrm{T}_{\text {tabel }}$ yaitu sebesar $1.785<1.988$ dan nilai signifikansi sebesar $0.079>0.05$, maka dapat disimpulkan bahwa variabel kemudahan penggunaan berpengaruh tidak signifikan terhadap minat nasabah menggunakan mobile banking.

Kemudahan penggunaan transaksi dalam layanan mobile banking dapat memudahkan nasabah bertransaksi perbankan seperti melakukan transfer sesama bank ataupun transfer ke bank lain, dimana transaksi mobile banking dapat dilakukan kapan pun dan dimana pun dan dapat mempermudah nasabah yang memiliki kesibukan, dengan mobile banking nasabah dapat melakukan transaksi kapan pun sehingga nasabah tidak perlu datang ke bank untuk melakukan transaksi perbankan.

\section{KESIMPULAN DAN SARAN}

Berdasarkan hasil pembahasan penelitian tersebut diatas, maka penulis dapat mengambil beberapa kesimpulan dari hasil penelitian ini sebagai berikut :

1. Variabel manfaat tidak berpengaruh signifikan terhadap minat nasabah menggunakan mobile banking.
2. Variabel kepercayaan tidak berpengaruh signifikan terhadap minat nasabah menggunakan mobile banking.

3. Variabel Kemudahan Penggunaan tidak berpengaruh signifikan terhadap minat nasabah menggunakan mobile banking.

4. Variabel Manfaat, Kepercayaan dan Kemudahan Penggunaan secara bersama - sama berpengaruh signifikan terhadap minat nasabah menggunakan mobile banking, akan tetapi variabel manfaat, kepercayaan, dan kemudahan penggunaan secara parsial tidak satupun mempengaruhi minat nasabah menggunakan mobile banking.

\section{PENELITIAN KEDEPAN}

Berdasarkan pada analisis dan kesimpulan yang berkaitan dengan penelitian ini, adapun penelitian kedepan yang dianjurkan adalah :

1. Saran bagi Bank MEGA Syariah Cabang Palu lebih meningkatkan promosi tentang layanan Mobile Banking kepada nasabahnya, Tampilan aplikasi mobile banking dapat dibuat lebih menarik dan lebih informatif lagi, agar tulisan dapat terbaca, Meningkatkan kembali layanan bantuan, karena masih banyak nasabah pengguna yang belum mengerti tentang penggunaan aplikasi tersebut, dan Agar dilakukan edukasi kepada nasabah yang baru membuka rekening untuk menginformasikan tentang aplikasi mobile banking untuk melakukan transaksi perbankan non tunai.

2. Saran bagi peneliti selanjutnya dapat terus mengembangkan penelitian ini. Selain itu juga peneliti selanjutnya diharapkan dapat menembah sampel 
penelitian yang lebih banyak dari penelitian sebelumnya,

3. Saran bagi nasabah harus mempercayai bank syariah, karena bank syariah menjalankan transaksi sesuai prinsip Islam, pengguna mobile banking harus tetap berhati-hati ketika melakukan transaksi, karena tidak semua menjadi tanggung jawab pihak bank

\section{DAFTAR PUSTAKA}

Aditya, Widjana Mahardika, Determinan Faktor Penerimaan Terhadap Internet Banking Pada Nasabah Bank Di Surabaya, Tesis, Sekolah Tinggi Ilmu Ekonomi Perbankan, 2010.

Al Fian, Junai . Pengaruh Kepuasan dan Kepercayaan Pelanggan Terhadap Loyalitas Pelanggan Auto 2000 Sungkono Surabaya, Jurnal Ilmu dan Riset Manajemen. Vol. 5. No. 6. 2016.

Amanullah, Bastian. Pengaruh Persepsi Manfaat, Kemudahan Penggunaan, dan Kepercayaan Terhadap Sikap Positif Penggunaan Layanan Mobile Banking. Skripsi Manajemen, Semarang, 2014.

Arifin, H. Djofa, Pengaruh Internet Terhadap Tingkat Kepercyaaan Nasabah Pada Bank BRI Syariah KCP Arjawinagun. Jurnal Vol.8. No.2. 2016.

Davis. Preived Usefulnes, Perceived Ease Of Use, And User Acceptance Of Information Tecnology. MS Quarterly, (Online) Vol. 13. 1989.
Departemen Agama. Al - Qur'an dan Terjemahan. Bekasi: Cipta Bagus Segara, 2015.

Dwityanti, Esthi. Analisis Faktor - Faktor Yang Mempengaruhi Minat Beli Konsumen Terhadap Layanan Internet Banking Mandiri. Tesis, Universitas Diponegoro, Semarang, 2008.

Ghozali, Imam ,Aplikasi Analisis Multivariate dengan Program SPSS, Cet.1, Semarang; Badan Penerbit Universitas Diponegoro, 2006.

Harlan, Dwi Mastia. Pengaruh Kemudahan Penggunaan, Kepercayaan, dan Resiko Terhadap Minat Bertransaksi Menggunakan E-Banking. Skripsi, Akuntansi, Yogyakarta, 2014.

Hasibuan, Malayu. Dasar - dasar Perbankan. Jakarta: Bumi Aksara, 2008.

Ismail. Perbankan Syariah. Jakarta: Prenada Media Group, 2011.

Jalil, A. (2019). Pengaruh Beban Kerja, Stres Kerja dan Lingkungan Kerja Terhadap Kinerja Guru Madrasah Aliyah Negeri 2 Kota Palu. Jurnal Ilmu Perbankan dan Keuangan Syariah, 1(2), 117-134.

Kamus Pusat Pembinaan Dan Pengembangan Bahasa. Kamus Besar Bahasa Indonesia. Jakarta, 2011.

Komarudin, Kamus Perbankan. (Jakarta: Grafindo, 1994).

Kurniawan, David dan Hatane Samuel. Analisis Penerimaan Nasabah 
Terhadap Layanan Mobile Banking Dengan Menggunakan Pendekatan Technology Acceptance Model dan Theory Of Reasoned Action. Jurnal Manajemen Pemasaran, 2013. Vol. 1. No.1.

Martono, Nanang ,Metode Penelitian Kuantitatif, Edisi revisi 2, Cet. V ; Jakarta : PT. Rajagrafindo Persada, 2016.

Muhammad, Metode Penelitian Ekonomi Islam Pendekatan Kuantitatif, Cet. 1, Jakarta : Rajawali Pers, 2008.

Nurdin, N. (2018). Institutional Arrangements in E-Government Implementation and Use: A Case Study From Indonesian Local Government. International Journal of Electronic Government Research (IJEGR), 14(2), 44-63. doi: 10.4018/ijegr.2018040104

Nurdin, N., Azizah, W. N., \& Rusli, R. (2020). Pengaruh Pengetahuan,Kemudahan dan Risiko Terhadap Minat Bertransaksi Menggunakan Finansial Technology (Fintech) Pada Mahasiswa Institut Agama Islam Negeri (IAIN) Palu Jurnal Ilmu Perbankan dan Keuangan Syariah, 2(2), 199-222.

Nurdin, N., Musyawarah, I., Nurfitriani, N., \& Jalil, A. (2020). Pengaruh Pelayanan Mobile Banking Terhadap Kepuasan Nasabah (Studi Pada Mahasiswa Perbankan Syariah IAIN Palu) Jurnal Ilmu Perbankan dan Keuangan Syariah, 2(2), 87-104.
Nurdin, N., Stockdale, R., \& Scheepers, H. (2014). Coordination and Cooperation in E-Government: An Indonesian Local EGovernment Case The Electronic Journal of Information Systems in developing Countries, 61(3), 1-21.

Nurdin, N., Musyawarah, I., Nurfitriani, N., \& Jalil, A. (2020). Pengaruh Pelayanan Mobile Banking Terhadap Kepuasan Nasabah (Studi Pada Mahasiswa Perbankan Syariah IAIN Palu). Jurnal Ilmu Perbankan dan Keuangan Syariah, 2(1), 87-104.

Prayuda, Dicky. Wawancara Dengan Penulis. Di Bank MEGA Syariah Kota Palu. Palu, 8 Juni 2020.

Purbo, Ono W dalam Muhammad, Etika Bisnis Islam,Yogyakarta: Unit Penerbit dan Percetakan Akademi Manajemen Perusahaan YKPN, 2004.

Rajab, Badi'u. Pengaruh Kualitas Pelayanan Terhadap Kepuasan Nasabah Pada Bank DKI Syariah. Jakarta: UIN Syarif Hidayatullah, 2008.

Wibowo, Yandi. Analisis Tingkat Kesuksesan Menggunakan Mobile Banking Dengan Menggunakan Metode Respesifikasi Model Delone Dan Mclean. Skripsi Akuntansi, Surakarta, 2011. 